\title{
A Fungus-Inducible Pepper Carboxylesterase Exhibits Antifungal Activity by Decomposing the Outer Layer of Fungal Cell Walls
}

\author{
Hyo-Hyoun Seo, ${ }^{1}$ Ae Ran Park, ${ }^{2}$ Hyun-Hwa Lee, ${ }^{3}$ Sangkyu Park, ${ }^{1}$ Yun-Jeong Han, ${ }^{1}$ Quyen T. N. Hoang, \\ Gyung Ja Choi, ${ }^{4}$ Jin-Cheol Kim, ${ }^{2}$ Young Soon Kim, ${ }^{1,+}$ and Jeong-II Kim ${ }^{1,+}$

\begin{abstract}
${ }^{1}$ Department of Biotechnology and Kumho Life Science Laboratory, Chonnam National University, Gwangju 61186, Korea;
${ }^{2}$ Department of Agricultural Chemistry and Institute of Environmentally Friendly Agriculture, Chonnam National University;

${ }^{3}$ Department of Biology, Chosun University, Gwangju 61452, Korea; and ${ }^{4}$ Center for Eco-Friendly New Materials, Korea

Research Institute of Chemical Technology, Daejeon 34114, Korea
\end{abstract}

Accepted 29 November 2017.

\begin{abstract}
Colletotrichum species are major fungal pathogens that cause devastating anthracnose diseases in many economically important crops. In this study, we observed the hydrolyzing activity of a fungus-inducible pepper carboxylesterase (PepEST) on cell walls of $C$. gloeosporioides, causing growth retardation of the fungus by blocking appressorium formation. To determine the cellular basis for the growth inhibition, we observed the localization of PepEST on the fungus and found the attachment of the protein on surfaces of conidia and germination tubes. Moreover, we examined the decomposition of cell-wall materials from the fungal surface after reaction with PepEST, which led to the identification of 1,2-dithiane-4,5-diol (DTD) by gas chromatography mass spectrometry analysis. Exogenous DTD treatment did not elicit expression of defense-related genes in the host plant but did trigger the necrosis of $\boldsymbol{C}$. gloeosporioides. Furthermore, the DTD compound displayed protective effects on pepper fruits and plants against $C$. gloeosporioides and $C$. coccodes, respectively. In addition, DTD was also effective in preventing other diseases, such as rice blast, tomato late blight, and wheat leaf rust. Therefore, our results provide evidence that PepEST is involved in hydrolysis of the outmost layer of the fungal cell walls and that DTD has antifungal activity, suggesting an alternative strategy to control agronomically important phytopathogens.
\end{abstract}

Colletotrichum species are ascomycetes responsible for anthracnose diseases in a wide range of plant species, including many commercially important crops (Cannon et al. 2012; Crouch and Beirn 2009). One example is Colletotrichum gloeosporioides, a notable pathogen associated with over 470 different host species and the major causal agent of pre- or postharvest diseases in fruits such as avocado, banana, mango, coffee, strawberries,

${ }^{\dagger}$ Corresponding authors: Young Soon Kim; E-mail: youngskim@jnu.ac.kr and Jeong-Il Kim; E-mail: kimji@jnu.ac.kr

Funding: National Research Foundation of Korea (NRF) funded by the Ministry of Education, Science and Technology grant no. NRF-2014R1A1A2007413, the Next-Generation BioGreen 21 Program, Rural Development Administration, Republic of Korea grant no. PJ01332701, and by Chonnam National University, 2016-2017.

*The $\boldsymbol{e}$-Xtra logo stands for "electronic extra" and indicates that four supplementary figures are published online.

(c) 2018 The American Phytopathological Society and peppers (Cannon et al. 2012; Liu et al. 2016). Many Colletotrichum species are hemibiotrophs, having an initial biotrophic phase of infection in living plant tissues and a second, destructive necrotrophic stage of infection (Gan et al. 2013; Münch et al. 2008). Thus, they can cause severe necrotic sunken lesions on plant tissues, including fruits. This infection mode of Colletotrichum species makes its control extremely difficult during crop cultivation. In peppers (Capsicum annuum L.), major constraints to fruit production include Colletotrichum species that are the primary invaders on fruits, causing chilli anthracnose (Harp et al. 2008; Than et al. 2008). Immature, green-colored pepper fruits are vulnerable to the pathogens, producing widespread outbreaks of anthracnose disease. Despite large-scale breeding efforts to control anthracnose disease, it remains endemic, resulting in large reductions of annual yields worldwide (Saxena et al. 2016). Therefore, it is necessary to develop methods for conferring resistance to anthracnose disease.

The conidia of Colletotrichum species are surrounded by cell walls that contain a fibrillar structure with chitin, $\beta$-glucans, and proteins (Fesel and Zuccaro 2016). The cell walls are covered by hydrophobic spore coats that are proteinaceous layers composed of hydrophobins (Bayry et al. 2012) and a very thin glycoprotein-lipid layer is additionally deposited on the surface of the conidial spore coats (Rawlings et al. 2007). Furthermore, ultrastructure analysis has revealed that hydrated spores are attached by mucilage and start to secrete extracellular matrix during germination (O'Connell et al. 1996). Both the mucilage and the extracellular matrix act as adhesives, although their components are not exactly known. To establish infection, the germinated spores enter the host epidermis using a specialized structure, called appressorium, and biotrophic hypha grow in the living epidermal cells. Once $C$. gloeosporioides switches to a necrotrophic mode of growth, host subepidermal cells are rapidly colonized by secondary hypha that cause extensive degradation of plant cell walls and eventually kill the cells (O'Connell et al. 2012). At the final stage of infection, brown to black spots become sunken on the rind tissues of fruits, where the fungus generates sporulating structures bearing asexual spores.

Molecules associated with pathogens can be recognized by host cells, resulting in activation of plant defense systems. When the components of fungal cell walls are degraded, the fragments of fungal macromolecules often serve as a potent elicitor of plant defense reactions, resulting in host plant protection by preventing fungal germination or penetration into host tissues (Segonzac and Zipfel 2011). Therefore, the disruption of cell walls exerts substantial effects on the development 
and growth of fungal pathogens during the phytopathogen interaction. However, the fibril coat that covers the surface of spores can disturb the recognition of fungal molecules by plant cells. Thus, the coat is known to have a critical role in masking the immunogenicity of fungal spores, interfering with the activation of host immune systems (Gow et al. 2017). In this regard, the cell-wall components of fungal pathogens can be considered as a potential target to obtain antifungal agents. To date, most identified plant hydrolases that degrade fungal cell walls have glucanase or chitinase activity (Oliveira-Garcia and Deising 2013). However, to develop a new fungal management strategy for crop cultivation, it would be valuable to find other fungal cell-wall hydrolases encoded in the host plant genome.

Previously, we isolated a pepper carboxylesterase, PepEST, that is highly expressed during the incompatible interaction between ripe pepper fruits and C. gloeosporioides (Kim et al. 2001b). Potential antifungal effects of PepEST were then evaluated, using in vitro experiments that showed growth inhibition of fungal pathogens (Kim et al. 2001b) and, more recently, using transgenic plants expressing PepEST (Cho et al. 2011; Ko et al. 2016). Since PepEST has hydrolytic activity for acyl compounds and accumulates in the infection site, it is speculated that the PepEST protein hydrolyzes the cell walls of $C$. gloeosporioides. In this study, we investigated the hydrolytic activity of PepEST protein on the conidia of $C$. gloeosporioides. We found that the PepEST protein was attached to the outer layer of cell walls and decomposed the surface, exposing fibril structure of the cell walls. Moreover, we identified a dithiane compound from the enzymatic reaction of PepEST with the fungus, which displayed antimicrobial activity against various fungal pathogens. Therefore, the present study may provide a new strategy to control agronomically important phytopathogens.

\section{RESULTS}

Inhibition of fungal development by PepEST.

To establish a compatible interaction, the conidia of C. gloeosporioides start to germinate on the surface of unripe pepper fruits at $1 \mathrm{~h}$ after inoculation (hai) and produce germination tubes with a swollen tip forming appressoria at about 6 hai. However, we previously showed that normal development of the fungus was severely impaired by the application of recombinant PepEST protein (Kim et al. 2001b; Ko et al. 2016). In this study, the fungal morphology on the unripe pepper fruits was investigated using a scanning electron microscope (Fig. 1). For this, the spores of $C$. gloeosporioides were inoculated onto the unripe pepper fruits with simultaneous treatment of PepEST protein and were incubated for $24 \mathrm{~h}$. As a control, the fungal growth also proceeded in distilled water to observe the usual germination tubes and appressoria (Fig. 1A). With the treatment of PepEST (at 0.01 and $0.1 \mathrm{mg} / \mathrm{ml}$ ), the appressoria did not develop from the fungus but the growing tips of germination tubes tended to elongate and sometimes produced new conidia at a lower concentration of PepEST (Fig. 1B and C). At a higher concentration of the protein $(0.25 \mathrm{mg} / \mathrm{ml})$, the growing fungus showed severe abnormality (Fig. 1D). These results are consistent with the previous result that PepEST suppressed appressorium development of $C$. gloeosporioides.

Since growth was severely affected by treatment with PepEST, the viability of the fungus was then examined by staining with two-color fluorescence dyes (Supplementary Fig. $\mathrm{S} 1)$. The stains have distinct spectral characteristics that represent the differences in their ability to penetrate fungal-cell membranes such that cells with intact membranes were labeled with green fluorescence, whereas cells with damaged membranes stained with red fluorescence. The results showed that
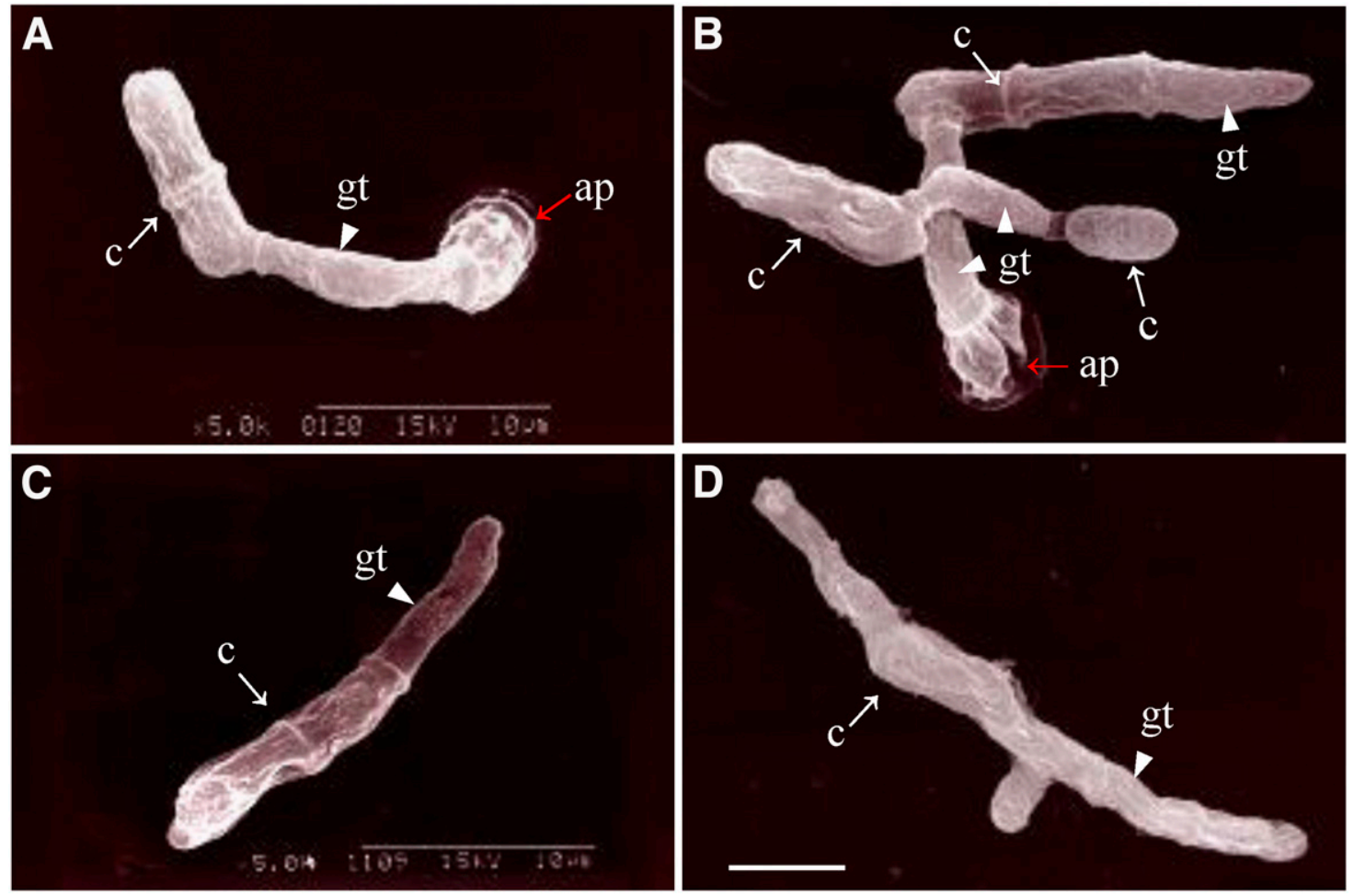

Fig. 1. Electron micrographs representing abnormal fungal growth on unripe pepper fruits amended with pepper carboxylesterase (PepEST) protein. Conidia of Colletotrichum gloeosporioides were inoculated on unripe pepper fruits with different concentrations of recombinant PepEST protein, and fungal morphology on the fruits at $24 \mathrm{~h}$ after inoculation (hai) was observed using a scanning electron microscope. A, Control conidia treated with distilled water. B to D, Conidia treated with PepEST at concentrations $(\mathrm{mg} / \mathrm{ml})$ of $0.01,0.1$, or 0.25 , respectively. ap $=$ appressorium, $\mathrm{c}=\mathrm{conidium}$, and gt $=$ germination tube . Bar $=5 \mu \mathrm{m}$ 
the viability of the fungus was significantly affected even at a low concentration $(0.01 \mathrm{mg} / \mathrm{ml})$ of PepEST protein. In addition, fungal viability decreased by PepEST treatment in a dosedependent manner. Compared with the control treated with distilled water, the treatment of 0.01 and $0.1 \mathrm{mg} / \mathrm{ml}$ PepEST for $3 \mathrm{~h}$ reduced, by approximately 6 and 18\%, fungal viability; the effective concentration for $50 \%$ loss of viability was estimated to be $1.26 \pm 0.06 \mathrm{mg} / \mathrm{ml}$ in our experimental conditions. These data indicate that the growth of $C$. gloeosporioides was affected
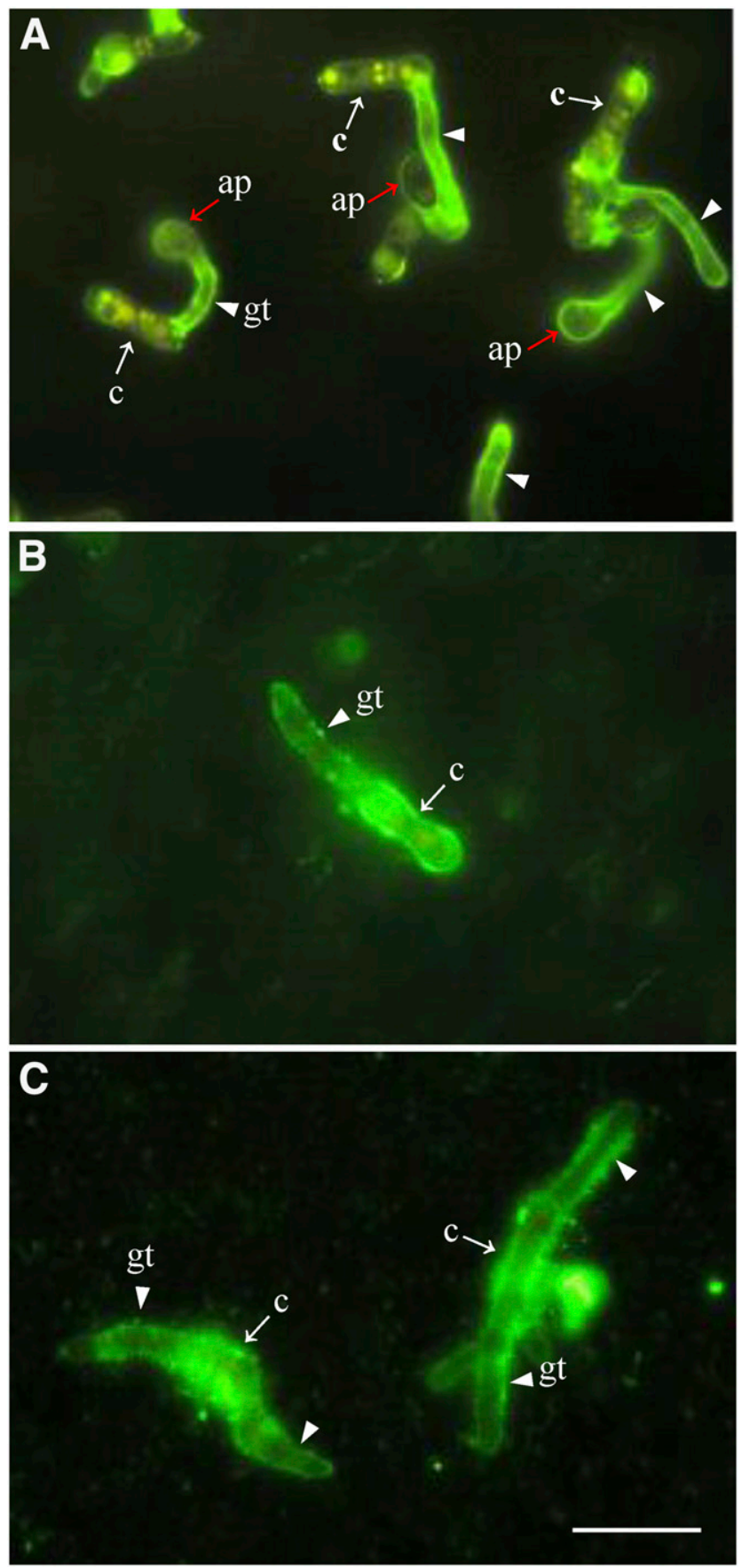

Fig. 2. Fluorescence labeling of Colletotrichum gloeosporioides cell walls after treatment with pepper carboxylesterase (PepEST). Conidia amended with PepEST were incubated for $24 \mathrm{~h}$, and then, fluorescein isothiocyanatelabeled concanavalin A was applied. Conidia were treated with $\mathbf{A}$, distilled water or $\mathbf{B}$, PepEST protein at concentrations of 0.1 and $\mathbf{C}, 0.25 \mathrm{mg} / \mathrm{ml}$. ap = appressorium (red arrow), $\mathrm{c}=$ conidium (white arrow), $\mathrm{gt}=$ germination tube (white arrowhead). Bar $=10 \mu \mathrm{m}$ by treatment with PepEST, causing the loss of spore viability and growth suppression of the fungus.

\section{Surface damage of the fungus}

after the exogenous treatment with PepEST.

Since PepEST is a hydrolase with carboxylesterase activity, it is speculated that the surface of the fungus might be decomposed. To observe the damage of the fungal surface, PepEST-treated fungus was further examined using fluorescence microscopy and field-emission scanning electron microscope (FE-SEM). First, fluorescein isothiocyanate (FITC)-labeled concanavalin A that binds to the glycoproteins on the surface of cell walls was used to observe the fungal surface by fluorescence microscopy (Fig. 2). In the control sample that was treated with distilled water, we observed an even fluorescence surrounding the germination tubes of the fungus, but little florescence on conidia or fully-matured appressoria (Fig. 2A). However, PepESTtreated fungus appeared severely altered without appressorium development (Fig. 2B and C). As a result, the boundaries of conidia were intensely labeled with FITC at the concentration of $0.1 \mathrm{mg} / \mathrm{ml}$, which was not shown in the control. Additionally, tattered edges with strong fluorescence were observed on the surface of the fungus at a higher concentration $(0.25 \mathrm{mg} / \mathrm{ml})$. These results might indicate the decomposition of outer layers of the conidia. Next, ultrastructures of the fungal surface were observed with FE-SEM (Fig. 3). When distilled water was treated as a control, the surface of the conidium was covered with an amorphous mucilage layer (Fig. 3A). In contrast, twisted fibers without the mucilage layer were observed on the outer surface of cell walls after PepEST treatment (Fig. 3B). These data indicate that the PepEST protein substantially modified the

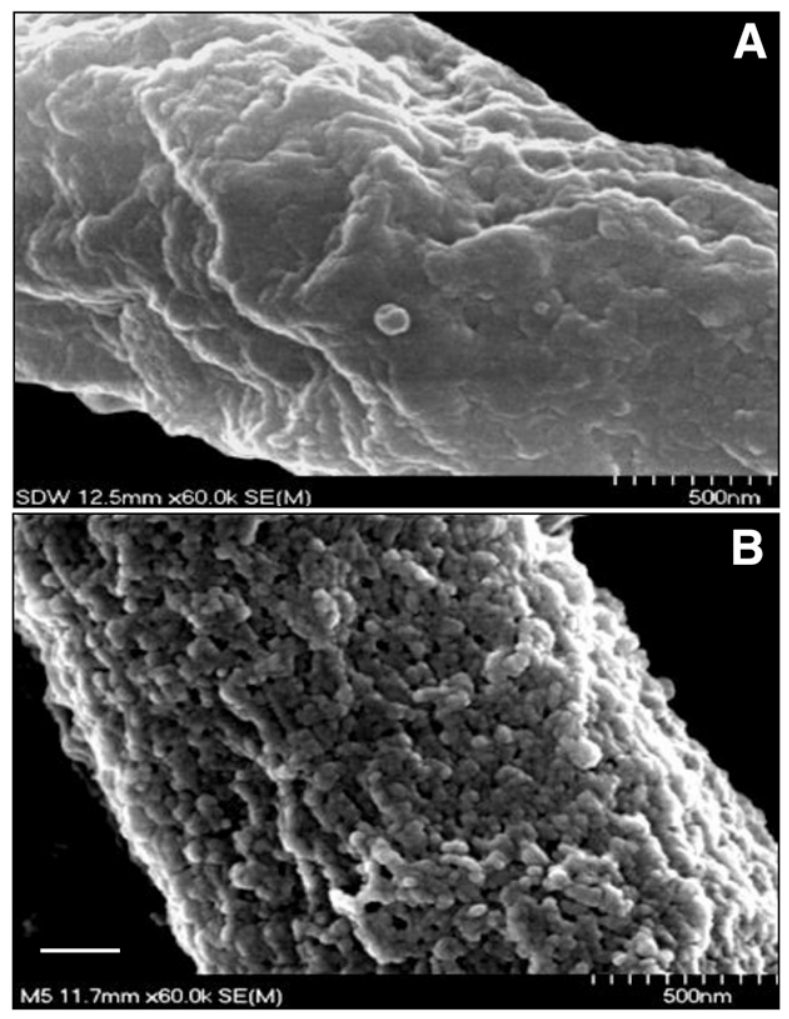

Fig. 3. Scanning electron micrographs representing the surface of Colletotrichum gloeosporioides after treatment with pepper carboxylesterase (PepEST). A, Conidium in distilled water. B, Conidium treated with PepEST. Conidia of $C$. gloeosporioides amended with PepEST were incubated on cover glasses for $24 \mathrm{~h}$, and electron micrographs were taken by field-emission scanning electron microscope (FE-SEM). The conidia incubated in distilled water is shown as a control. $\mathrm{Bar}=200 \mathrm{~nm}$. 
materials surrounding the cell walls of conidia and germination tubes. In addition, the alteration of fungal surface by PepEST suggests that the hydrolysis of cell-wall components might constitute a critical step in the antifungal effects of PepEST during the phytopathogen interaction.

\section{Analysis of compounds released after the degradation of fungal cell walls by PepEST.}

To further investigate the localization of PepEST protein in C. gloeosporioides, we labeled PepEST and GST (glutathione $S$-transferase) proteins with FITC, which is used to attach a fluorophore to a protein via an amine group. The FITC-labeled PepEST and GST proteins displayed green fluorescence on gels, corresponding to protein bands of 36.5 and $27 \mathrm{kDa}$, respectively (Fig. 4A). With the treatment of FITC-labeled proteins, we found that the FITC-labeled PepEST protein was mostly detected on the outer surface of the fungus, at 24 hai (Fig. 4B). In contrast, the FITC-labeled GST protein accumulated inside the fungal cells (Fig. 4C), which is consistent with the previous report that the GST protein could be translocated from the external medium into many different cell types (Morris et al. 2011). These results also suggest that the growth and differentiation of the fungus were not affected by the FITClabeled GST protein, whereas the FITC-labeled PepEST protein resulted in impaired development of appressoria.

Since PepEST has a hydrolase activity and localizes on the outer surface of the fungus, we then analyzed materials decomposed from the fungus by the enzymatic activity of PepEST, using gas chromatography mass spectrometry (GC-MS). In our experimental conditions, two major compounds were identified
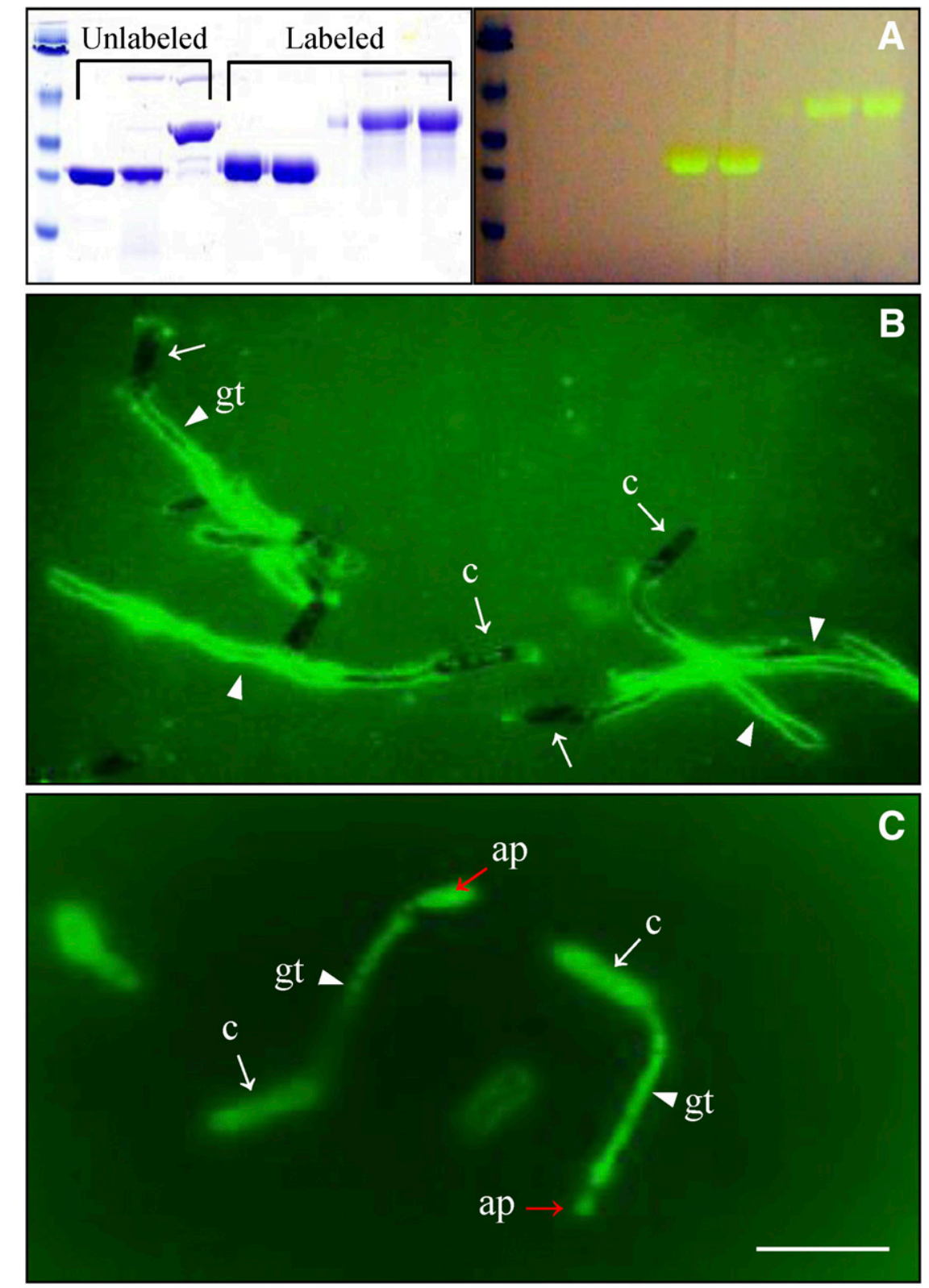

Fig. 4. Localization of fluorescein isothiocyanate (FITC)-labeled pepper carboxylesterase (PepEST) on the surface of Colletotrichum gloeosporioides. A, FITC-labeled glutathione $S$-transferase (GST) and PepEST proteins. Left, Coomassie brilliant blue-stained gel of the purified proteins. Right, fluorescence visualization of FITC-labeled proteins on the left gel under UV light. Purified protein $(3 \mu \mathrm{g})$ was loaded in each lane. Lane 1, protein marker; lanes 2 and 3 , purified GST protein; lane 4, purified PepEST protein; lanes 5 and 6, FITC-labeled GST protein; lanes 8 and 9, FITC-labeled PepEST protein. B, Cellular localization of FITC-labeled PepEST and C, GST proteins on the conidia of $C$. gloeosporioides. Conidia treated with FITC-labeled PepEST were incubated for $24 \mathrm{~h}$, and green fluorescence was observed using a fluorescence microscope. FITC-labeled GST was used as a control. ap $=$ appressorium (red arrow), $\mathrm{c}=$ conidium (white arrow), $\mathrm{gt}=$ germination tube (white arrowhead). $\mathrm{Bar}=10 \mu \mathrm{m}$. 
by comparisons with mass spectrum profiles of the authentic compounds (Fig. 5). They are glycerol and 1,2-dithiane-4,5diol (DTD), which accounted for 44.3 and $16.8 \%$ of the extract, respectively. These results suggest that DTD is one of the main compounds produced from the enzymatic reaction of PepEST with the fungus. Although the DTD compound is expected to be derived from the outmost structural layer containing a dithianediol-related compound linked to a glycerol, there is no such compound reported as a fungal component until now. Thus, we further investigated the antifungal activity of DTD against C. gloeosporioides.

\section{In vitro antifungal activity of DTD.}

To assess antifungal activity, we treated various concentrations of DTD to conidia suspension of C. gloeosporioides and the fungal growth was observed using a microscope (Fig. 6). It is noted that $1 \%$ dimethyl sulfoxide (DMSO) solution was used as a control for these assays, and 0.5 and 1\% DMSO did not affect to the viability of $C$. gloeosporioides in our experimental conditions. With the application of DTD, spore germination and appressorium formation were significantly inhibited in a dose-dependent manner (Fig. 6A). At a low concentration of DTD $(0.1 \mathrm{mg} / \mathrm{ml})$, we observed that the conidia maintained the viability, with little effect on germination, but appressorium formation was significantly reduced compared with that of the control (Fig. 6A). Application of $0.1 \mathrm{mg}$ of DTD per milliliter exhibited approximately $50 \%$ inhibitory effect on appressorium formation. In the case of DTD application at $2.5 \mathrm{mg} / \mathrm{ml}$, in addition to significant reduction in fungal growth, we observed impaired fungal viability that was shown in red after staining with a Live/Dead BacLight viability kit (Fig. 6B). We also found that effective concentrations $\left(\mathrm{EC}_{50}\right)$ of DTD were estimated to be $1.88 \pm 0.13$ and $0.63 \pm 0.17 \mathrm{mg} / \mathrm{ml}$ for spore germination and appressorium formation, respectively, suggesting that DTD is an active agent against $C$. gloeosporioides. Moreover, we conducted flow cytometry (FACS) analysis with DTD-treated conidia of $C$. gloeosporioides to investigate the viability of spores. Since the increment of cells in the upper left zone of FACScan profiles represents the uptake of propidium iodide (PI) by the conidia, the results showed that DTD induced the influx of PI into cells, representing nonviable cells (Fig. 6C). Spores exposed to a higher concentration of DTD $(5 \mathrm{mg} / \mathrm{ml})$ were more necrotic than those exposed to a lower concentration $(2 \mathrm{mg} / \mathrm{ml})$. Thus, these results demonstrate that DTD induces necrosis of the spore cells in a dose-dependent manner.

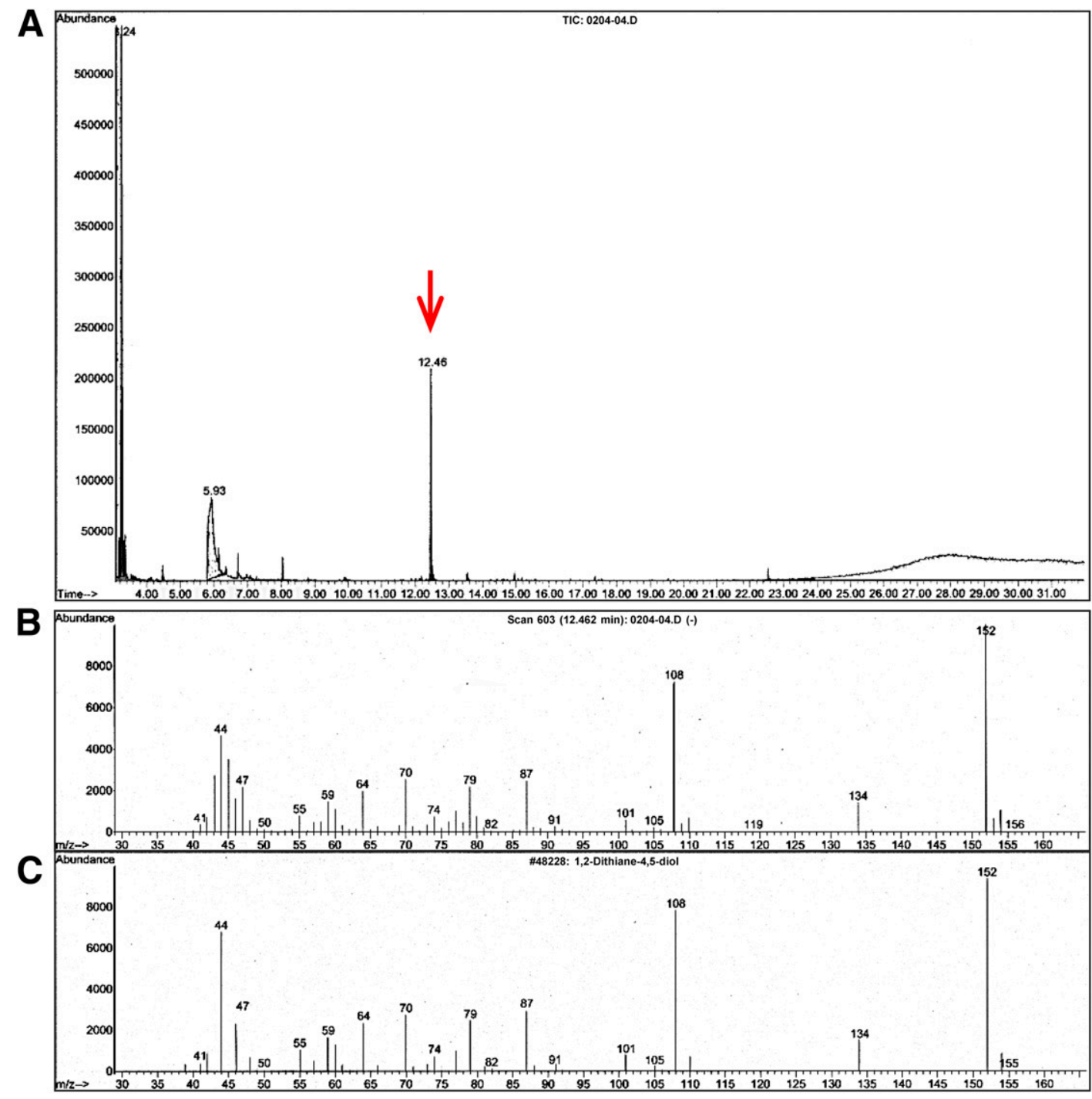

Fig. 5. Gas chromatography mass spectrometry (GC-MS) analysis of hydrolyzed materials from Colletotrichum gloeosporioides treated with pepper carboxylesterase (PepEST). After incubation of conidia with PepEST protein for $24 \mathrm{~h}$, the soluble fraction was extracted and analyzed by GC-MS. A, GC profile. B, Mass spectrum of a peak at $12.46 \mathrm{~min}$ (the arrow in A). C, Mass spectrum of authentic 1,2-dithiane-4,5-diol. 
In vivo antifungal activity of DTD against Colletotrichum species.

To assess the efficacy of DTD against the anthracnose fungi, C. gloeosporioides spores were inoculated onto the surface of green pepper fruits with simultaneous treatment (Fig. 7A) or pretreatment of DTD (Supplementary Fig. S2). Both results were similar, in that significant dose-dependent effects of DTD on lesion formation were observed. Eight days after inoculation, control fruits (i.e., DW or V) showed typical sunken anthracnose disease symptoms of spreading lesions covered with soaked spores (Fig. 7A). In contrast, lesion formation and spore production were significantly inhibited in a dose-dependent manner on the fruits with simultaneous DTD treatment (Fig. 7B). Necrotic lesions were hardly observed on the pepper fruits treated with $0.5 \mathrm{mg} / \mathrm{ml}$ of DTD, in which the number of spores in the fruits was drastically lowered $(\sim 5 \%)$ compared with the
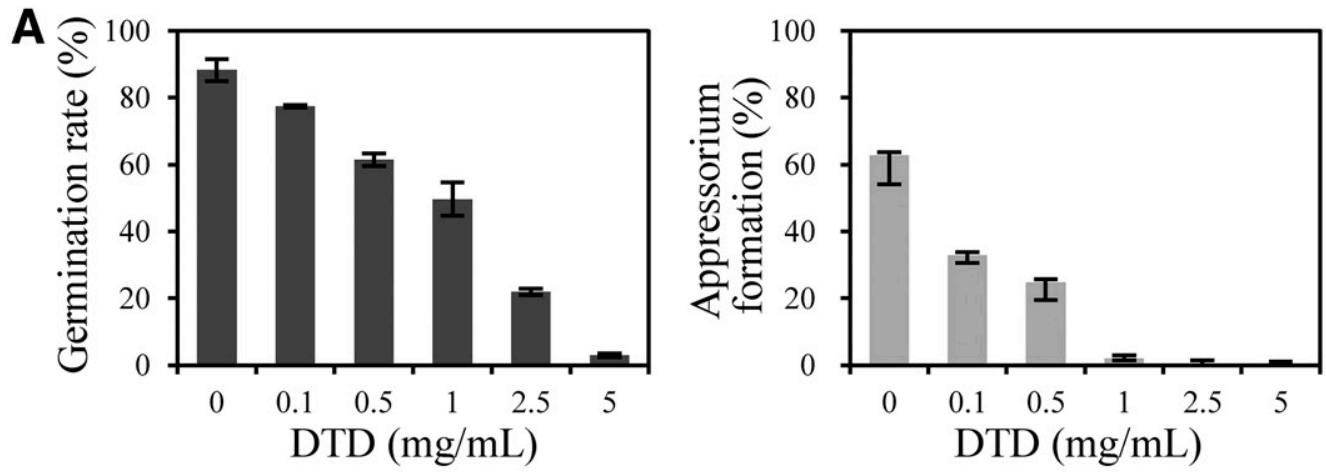

B

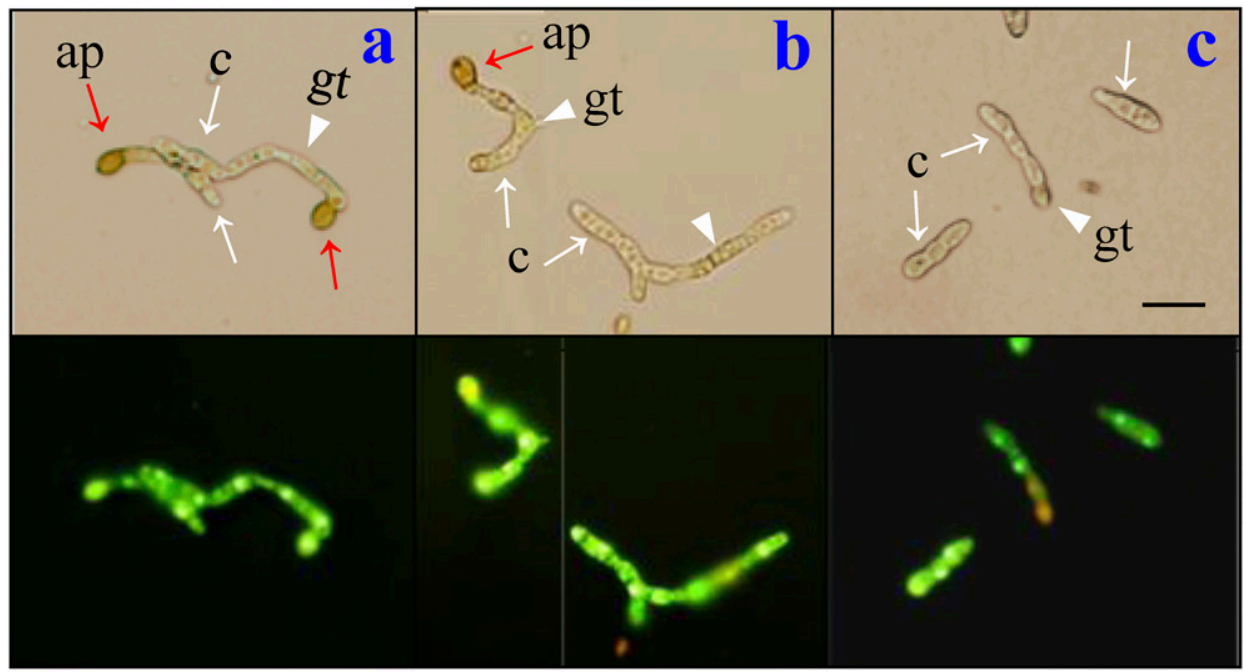

C
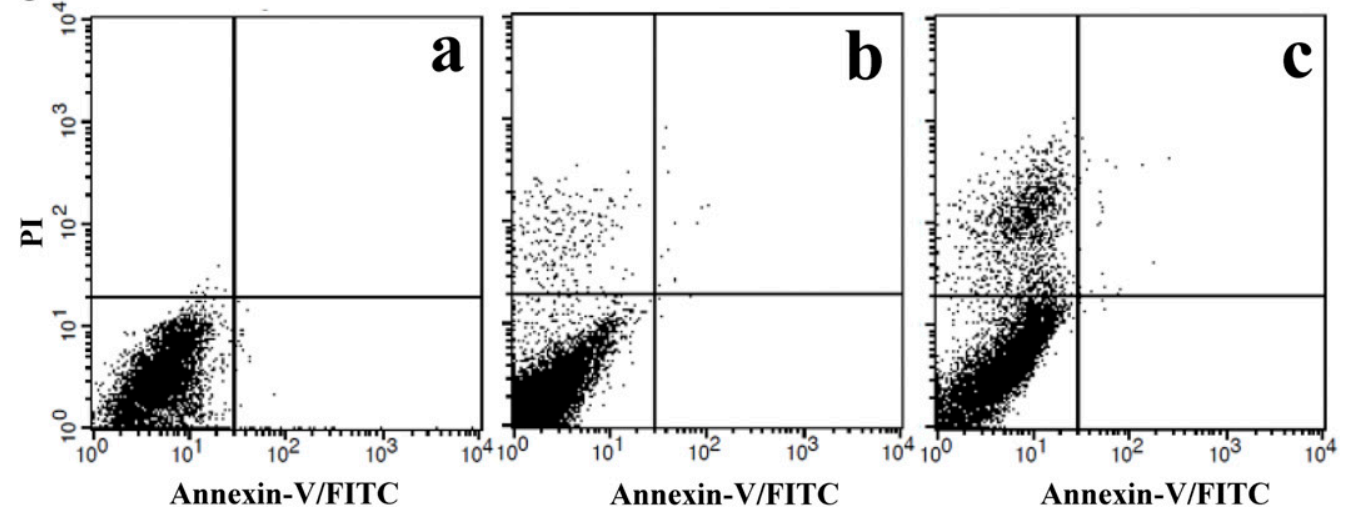

Fig. 6. Effects of 1,2-dithiane-4,5-diol (DTD) on the growth of Colletotrichum gloeosporioides. A, Spore germination and appressorium formation. Spore suspensions were amended with DTD to the final concentrations indicated. A minimum of 300 spores were counted per replicate. Each value represents the mean \pm standard deviation of three replicates. B, Fungal morphology of $C$. gloeosporioides after treatment with DTD. Fungi at $24 \mathrm{~h}$ after treatment were stained with the Live/Dead BacLight viability kit and were then observed under light (upper) and fluorescence (lower) microscopes. Conidia in $1 \%$ dimethyl sulfoxide (DMSO) solution were shown as a control (panel a). Conidia were treated with DTD at concentrations of 1.0 (b) and $2.5 \mathrm{mg} / \mathrm{ml}(\mathrm{c})$. ap = appressorium (red arrow), $\mathrm{c}=$ conidium (white arrow), gt $=$ germination tube (white arrowhead). Bar $=5 \mu \mathrm{m}$. C, Flow cytometry analysis of $C$. gloeosporioides spores after treatment with DTD to show the ratio of cell death. The populations of conidia in $1 \%$ DMSO solution are shown as a control (a), along with those treated with DTD at concentrations of 2.0 (b) and $5.0 \mathrm{mg} / \mathrm{ml}(\mathrm{c})$. 
DTD-untreated control. The epidermal cells of inoculated pepper fruits remained healthy with the treatment of $1.0 \mathrm{mg} / \mathrm{ml}$ DTD (Fig. 7A). These results are consistent with the expectation that DTD treatment might lead to a lower colonization of the fungus. Additionally, we also pretreated DTD on pepper fruits for $1 \mathrm{~h}$ and then inoculated with $C$. gloeosporioides on the DTD-pretreated regions of fruits, for the investigation of the protective effect of DTD against the anthracnose disease. The results showed that DTD pretreatment could also prevent the legion formation and disease development. Moreover, we used another pathogen, $C$. coccodes, the causal agent of seedling anthracnose that is isolated from infected leaves of pepper and exhibits strong pathogenicity to seedlings. For this, DTD solutions were sprayed onto the pepper plants, and $24 \mathrm{~h}$ later, the DTD-treated plants were inoculated with the spore suspension of $C$. coccodes. The results showed that pepper plants sprayed with DTD remained healthy showing a normal growth, whereas the control plant (i.e., without DTD pretreatment) displayed severe blight symptoms with a retarded growth (Fig. 7C). The susceptible pepper plants exhibited dramatic resistance against $C$. coccodes after pretreatment with increasing concentrations of DTD. Taken together, these results suggest that DTD treatment prevents the spread of anthracnose symptoms in pepper by inhibiting the growth of Colletotrichum species.

\section{Antifungal bioassays of DTD \\ against various phytopathogenic fungi.}

We further conducted in vivo antifungal activity assays of DTD against six plant diseases, which included rice blast (RCB, caused by Magnaporthe grisea), rice sheath blight (RSB, by Corticium sasaki), tomato gray mold (TGM, by Botrytis cinerea), tomato late blight (TLB, by Phytophthora infestans) and wheat leaf rust (WLR, by Puccinia recondite), as well as red pepper anthracnose (RPA, C. coccodes). The phytopathogens for plant diseases were selected for the in vivo assays in rice, tomato, wheat, and pepper, and greenhouse experiments were carried out for each plant and pathogen combination. After spraying with different concentrations of DTD, the disease control values were estimated as the percentage of healthy area in infected leaves versus uninfected control leaf area. The results showed the highest disease control values for RPA, in which almost no anthracnose symptom was observed after treatment with $1.00 \mathrm{mg} / \mathrm{ml}$ DTD (i.e., 99\% disease control) (Table 1). In addition, DTD effectively prevented RCB and
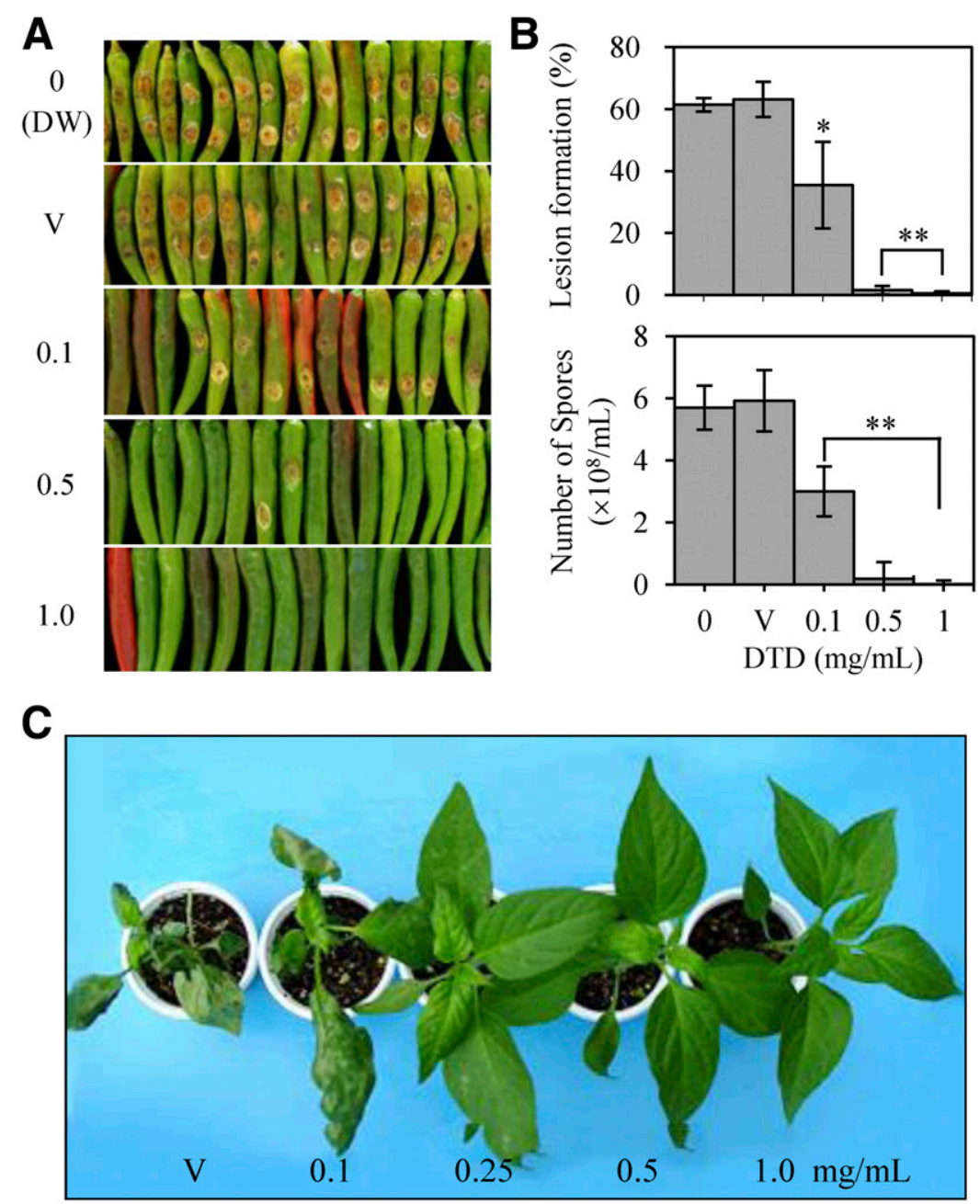

Fig. 7. Effects of 1,2-dithiane-4,5-diol (DTD) treatment on infected pepper fruits with Colletotrichum species. A, DTD was dissolved in $1 \%$ dimethyl sulfoxide that was used as vehicle (V) in this analysis. Representative unripe green pepper fruits inoculated with Colletotrichum gloeosporioides. C. gloeosporioides amended with DTD $(0, \mathrm{~V}, 0.1,0.5,1[\mathrm{mg} / \mathrm{ml}])$ was applied to unripe pepper fruits. Inoculated fruits were photographed at 8 days after infection. B, Lesion formation and number of spores in the inoculated fruits. Statistically significant changes compared with uninoculated control fruits are indicated by asterisks (* and $*^{*}$ ) representing $P<0.05$ and 0.01 , respectively, using one-way analysis of variance. At least 50 fruits were counted per replicate. Each value represents the mean \pm standard deviation of three replicates. C, In vivo antifungal activity assay of DTD on pepper plants against $C$. coccodes. For this analysis, pepper seedlings were first sprayed with different concentrations of DTD as indicated, and then, after $24 \mathrm{~h}$, the pretreated seedlings were inoculated with $C$. coccodes by spraying a spore suspension $\left(5 \times 10^{5} / \mathrm{ml}\right)$. The photograph was taken at 4 days after infection. 
TLB diseases (97 and $96 \%$ disease control with $1.00 \mathrm{mg} / \mathrm{ml}$ DTD), but showed little effect on RSB and TGM. In the case of WLR, only a high concentration of DTD was shown to have an inhibitory effect. The results also showed a strong correlation between treated DTD concentration and the protection of susceptible plants against phytopathogens. Overall, these results provided the biological evidence that DTD possesses antifungal activities against other phytopathogens, in addition to Colletotrichum species.

\section{The effect of DTD treatment on defense reactions in pepper tissues.}

Since DTD treatment could confer disease resistance to susceptible pepper fruits against the anthracnose fungi, we examined whether DTD treatment induces defense reactions in pepper fruits. For this, we investigated the expression of pathogenesisrelated $(P R)$ genes that are used as molecular markers of defense responses in plants. As expected, the expression of $P R 3$, $P R 4$, and PR5 was induced upon inoculation of the anthracnose fungus (Supplementary Fig. S3). In contrast, the induction of $P R$ genes was significantly suppressed when DTD was amended in the inoculated spores. This data might be consistent with the results showing that the formation of appressoria and fungal penetration were suppressed by the action of DTD (Fig. 7). In addition, we confirmed that the transcript levels of $P R$ genes were not changed significantly in the pepper fruits at $24 \mathrm{~h}$ after the treatment of DTD alone, compared with the control. These results indicate that the DTD treatment might not have an effect on the plant defense response.

We also investigated the protein expression profiles of normal pepper fruits and fungus-infected fruits using 2D-gel proteomic analysis (Supplementary Fig. S4). The results showed differential expression of proteins between uninfected and infected tissues; as highlighted, PR10 proteins were highly induced in the fungus-infected fruits. In contrast, PR10 was not induced by DTD treatment, and the induction in fungusinfected fruits was significantly suppressed by DTD treatment, which is consistent with transcript expression pattern of $P R$ genes in fungus-infected fruits after DTD treatment. Our results showed that the protein expression profile in DTD-treated fruits was not changed significantly compared with that in control fruits, suggesting that DTD does not affect the protein expression in pepper fruits.

\section{DISCUSSION}

The fungal cell wall has vital roles in maintaining the shape and integrity of the cell in diverse environments, which is crucial for fungal growth, pathogenesis, and survival. In this regard, the disruption of the wall structure has significant effects on the fungal cell. Since most plant pathogenic fungi contain chitins and $\beta$-glucans as cell-wall components (Bowman and Free 2006; Fesel and Zuccaro 2016), many plants possess chitinases (EC 3.2.1.14) and $\beta$-glucanases (EC 3.2.1.6) that are produced in significant quantities to defend against infection with chitinand glucan-containing pathogens (Ménard et al. 2004). Some of these hydrolases are also known as PR proteins, for example, PR2 and PR3 for glucanase and chitinase, respectively, that are important for plant defense in response to the attack of phytopathogens (van Loon et al. 2006). In this study, we discovered that the fungus-inducible pepper carboxylesterase, PepEST, decomposes the outer layer of the cell wall of $C$. gloeosporioides, the causal agent of pepper fruit anthracnose.

Plant carboxylesterases (EC 3.1.1.1) consist of a large family in a plant genome: for example, 20 and 48 genes in Arabidopsis thaliana and Oryza sativa, respectively. Among them, pathogeninducible carboxylesterases have received attention for their possible role in the detoxification of pathogen-derived compounds (Aranda et al. 2014; Cummins et al. 2007). As examples, a tobacco esterase gene, hsr203J, has been isolated in a hypersensitive reaction against Ralstonia solanacearum (Pontier et al. 1998). In Arabidopsis, EDS1 was found to be an essential component of $R$ gene-mediated disease resistance (Bhattacharjee et al. 2011), and $P A D 4$ is known to be required for the expression of multiple defense responses to provide resistance against pathogens (Feys et al. 2001). Furthermore, a substrate specificity study of plant carboxylesterases suggested that diverse hydrolases are involved in the secondary metabolism of plants (Cummins et al. 2007). However, the targets for their hydrolytic activity have not been determined.

In our previous study, PepEST protein was shown to inhibit appressorium formation in C. gloeosporioides, which resulted in the protective effect on pepper fruits against the anthracnose fungus (Kim et al. 2001b; Ko et al. 2005). More recently, we showed that PepEST treatment led to a potentiated state for disease resistance in pepper fruits, conferring anthracnose disease resistance to transgenic pepper plants expressing PepEST (Ko et al. 2016). In the present study, we found that the PepEST protein was attached to the conidium cell wall of $C$. gloeosporioides (Fig. 4) and showed hydrolytic activities on the cell surface (Figs. 2 and 3 ), which prevented the formation of appressoria and eventually fungal colonization at the initial infection stage (Fig. 1). Considering that recombinant PepEST protein expressed in Escherichia coli hydrolyzed the substrates containing ester bonds, such as $p$-nitrophenyl esters, the fungal cell-wall compounds containing ester bonds might be the substrates for PepEST. However, natural substrates for this carboxylesterase are not yet known.

Since PepEST could affect fungal morphogenesis by hydrolyzing the cell wall of the anthracnose fungus, we extended our work to investigate the cell-wall components that could be obtained after the enzymatic reactions of PepEST with C. gloeosporioides. To this end, we identified DTD from the reaction extract (Fig. 5). Then, we examined its antifungal activity and found that DTD effectively inhibited spore germination and appressorium formation in C. gloeosporioides (Fig. 6). Moreover, DTD treatment inhibited anthracnose disease development in pepper fruits and plants by $C$. gloeosporioides and C. coccodes (Fig. 7). Furthermore, DTD was also effective to prevent other diseases such as rice blast, tomato late blight, and

Table 1. In vivo disease control activities of 1,2-dithiane-4,5-diol (DTD) against six plant diseases

\begin{tabular}{|c|c|c|c|c|c|c|}
\hline \multirow[b]{2}{*}{ DTD (mg/ml) } & \multicolumn{6}{|c|}{ Disease control value $(\%)^{a}$} \\
\hline & RCB & RSB & TGM & TLB & WLR & RPA \\
\hline 1.00 & $97.0 \pm 1.20$ & $11.0 \pm 4.00$ & $8.00 \pm 7.10$ & $96.0 \pm 0.00$ & $93.0 \pm 2.10$ & $99.0 \pm 1.00$ \\
\hline 0.50 & $64.0 \pm 18.0$ & $11.0 \pm 4.00$ & $8.00 \pm 3.50$ & $90.0 \pm 1.50$ & $3.00 \pm 3.00$ & $94.0 \pm 1.50$ \\
\hline 0.25 & $14.0 \pm 0.00$ & $11.0 \pm 0.00$ & $17.0 \pm 3.10$ & $75.0 \pm 15.0$ & $3.00 \pm 3.00$ & $70.0 \pm 11.0$ \\
\hline
\end{tabular}


wheat leaf rust (Table 1). However, DTD did not show any protective effect on rice sheath blight and tomato gray mold, suggesting that DTD might act selectively on phytopathogens. Previously, we examined the antifungal activity of PepEST on fungal pathogens of creeping bentgrass, and found that PepEST protein was sufficient to inhibit the growth of the fungal pathogens, Rhizoctonia solani AG2-2 (IIIB) (causing brown patch) and Sclerotinia homoeocarpa (causing dollar spot), but not an oomycete responsible for pythium blight, Pythium aphanidermatum (Cho et al. 2011). This might be due to the difference in cell walls between true fungi and oomycetes, which might explain why the esterase is not very effective against $P$. aphanidermatum. Similarly, transgenic pepper with PepEST did not show resistance to another oomycete Phytophthora capsici, the causal agent of phytophthora blight (Ko et al. 2016). Therefore, DTD might be effective on some true fungi selectively.

The attempt to damage the cell walls of the infecting organism is part of the innate immune response in plants. This process produces fragments of cell-wall components that are potent elicitors of plant defense responses. In this regard, surface-damaged fungi by PepEST likely release hydrolyzed compounds that probably act as an elicitor for plant defense responses. In the present study, although we identified DTD from fungal digest, DTD treatment did not elicit defense responses in plants, as shown by the expression of pathogenesisrelated genes and proteins. This indicates that the DTD compound was not recognized by plant. Thus, further studies will be necessary to identify other potent elicitors from the hydrolyzed compounds.

Anthracnose diseases caused by Colletotrichum species are a major problem in field cultivation of pepper, resulting in significant losses to fruit production. Although extensive efforts have been taken to obtain pepper plants resistant to anthracnose, it is known to be very difficult due to high degree of variability in the fruit quality depending on climate and environmental conditions. Therefore, the demand for agrochemicals to control the anthracnose disease has greatly increased in recent years. In this respect, PepEST, studied here as a fungal cell-wall hydrolase, might provide a potential mechanism to control fungal pathogens. Especially, the DTD compound isolated from the enzymatic reactions between PepEST and fungal cell walls exhibited protective effects on crops against phytopathogens (Fig. 7 and Table 1). To our knowledge, this is the first report on the antifungal activity of DTD, although its functional mechanism needs to be clarified. Collectively, the present study represents that the PepEST protein militates against fungal pathogens to confer disease resistance to plants and that the DTD compound has antifungal activity against various fungal pathogens, providing a possible strategy for crop protection against agronomically important phytopathogens.

\section{MATERIALS AND METHODS}

\section{Fungal pathogens and plant materials.}

The monoconidial isolate of $C$. gloeosporioides (KG13) was cultured on potato dextrose agar for $7 \mathrm{~d}$ in darkness at $28^{\circ} \mathrm{C}$. Conidia were then harvested and suspended in sterile distilled water. Ten microliter of spore suspension $\left(5 \times 10^{5}\right.$ spores $\left./ \mathrm{ml}\right)$ was used for drop inoculation in vitro and in vivo. In addition, C. coccodes (KACC 40009) was used as an alternative anthracnose fungus for the inoculation of pepper. For the pepper fruits, the seeds of a commercial pepper (Capsicum annuum $\mathrm{L}$. cv. Nockkwang) were obtained from Heung Nong Seed Co. Ltd., Korea. Plants were grown at $25^{\circ} \mathrm{C}$ under greenhouse conditions. Fully grown, unripe green fruits from three-monthold plants were used for inoculation with the anthracnose fungus.

\section{Treatment of pepper fruits with PepEST protein.}

The glutathione S-transferase (GST)-fused PepEST protein was expressed in E. coli BL21 as described previously (Ko et al. 2005), and purified by PreScission Protease digestion according to the manufacturer's instructions (GE Healthcare Life Sciences). Briefly, the cDNA of PepEST (AF072533) in pGEX 6P-1 was expressed in E. coli cells, and the lysate bound to glutathione sepharose 4B was treated with $80 \mathrm{U}$ of PreScission protease in order to remove GST from the PepEST protein, and for purification. The protein concentration was determined by Bradford method, and the stock solution of PepEST protein was prepared to a final concentration of $1.0 \mathrm{mg} / \mathrm{ml}$, unless otherwise specified.

For the treatment of PepEST, $1 \mu \mathrm{g}$ of recombinant PepEST protein was added to $10 \mu \mathrm{l}$ of spore suspension $\left(\mathrm{ca} .5 \times 10^{3}\right.$ spores), and the mixture was applied to the unripe pepper fruits or cover glasses. As controls, sterile distilled water or the same amount of GST protein $(1 \mu \mathrm{g})$ was added to the spore suspension. The inoculated fruits were then incubated in a humidified chamber at $25^{\circ} \mathrm{C}$ in the dark for $24 \mathrm{~h}$. After incubation, the fruits were excised to $5 \mathrm{~mm}^{2}$ at the drop-inoculated site for further analysis.

\section{Observation of fungal morphology \\ by scanning electron microscope.}

Small segments of pepper fruits ( $5 \mathrm{~mm}$ long) were cut from the fungal infection site to observe the growth of $C$. gloeosporioides. The segments were vacuum-infiltrated in sodium phosphate buffer (pH 7.0) containing $2 \%$ sucrose, $3 \%$ paraformaldehyde, and $0.2 \%$ glutaraldehyde on ice for $6 \mathrm{~h}$. Following fixation, the specimens were slowly dehydrated in a graded ethanol series at room temperature. After the last change of absolute alcohol, the samples were immediately submitted to critical point drying and gold coating, and then observed with a field-emission scanning electron microscope (FE-SEM; HITACHI, S-4700). Additionally, conidia of $C$. gloeosporioides were amended with PepEST on cover glasses for $24 \mathrm{~h}$, and the fungal surface was observed with FE-SEM.

\section{Labeling of $C$. gloeosporioides cell wall with FITC-conjugated proteins.}

To investigate the surface structure of the fungus after PepEST treatment, fluorescein isothiocyanate (FITC)-labeled concanavalin A (Sigma) was used. After treatment of germinated fungi with $0.1 \mathrm{mg} / \mathrm{ml} \mathrm{FITC-concanavalin} \mathrm{A} \mathrm{for} 10 \mathrm{~min}$, the conidia were observed using a fluorescence microscope (Olympus, Japan). In addition, to examine the localization of PepEST on the fungus, FITC-labeled PepEST and GST were used. FITC (Sigma) was added to the purified protein to a final concentration of $1 \mathrm{mg} / \mathrm{ml}$, and then applied to a gel-filtration chromatography column (120 cm Sephadex G-50; Sigma) to remove unconjugated dye. Conjugation between FITC and PepEST was verified as intense fluorescent protein bands on $10 \%$ SDS-PAGE gel under UV light. As a control, FITClabeled GST protein was prepared and used for the analysis.

\section{Isolation and in vitro antifungal activity assay of DTD.}

Fungal spores in distilled water $\left(5 \times 10^{5}\right.$ spores $\left./ \mathrm{ml}\right)$ were reacted with PepEST protein $(0.1 \mathrm{mg}$ PepEST/ml spore suspension). After $24 \mathrm{~h}$, the soluble fraction was collected, lyophilized, and finally dissolved in chloroform. The extracts were then analyzed by GC-MS (Hewlett Packard). From the GC-MS analysis, glycerol and DTD were identified from the comparisons using mass spectrum profiles of the authentic compounds.

To examine in vitro antifungal activity assay, spore germination and appressorium formation was monitored after DTD treatment by microscopic examination. DTD was dissolved in 
DMSO to a final concentration of $100 \mathrm{mg} / \mathrm{ml}$, unless otherwise specified. The DTD stock solution was added to spore suspension, in which the mixture contained $1 \%$ DMSO (v/v). Thus, $1 \%$ DMSO solution was used as a control. Spore suspension (containing $5 \times 10^{3}$ spores) with different concentrations of DTD $(0.01$ $\sim 5 \mathrm{mg} / \mathrm{ml}$ ) were incubated on cover glasses for $24 \mathrm{~h}$ at $26^{\circ} \mathrm{C}$. Then, spore germination and appressorium formation were monitored at $3 \mathrm{~h}$ and $24 \mathrm{~h}$ after the treatment, respectively. The effect of DTD was also assessed to estimate effective concentration values (i.e., $\mathrm{EC}_{50}$ ) for the reductions in germination rate and appressorium formation. The experiments were conducted in triplicate.

\section{Viability assays of $C$. gloeosporioides.}

To observe the viability of the fungus, Live/Dead BacLight ${ }^{\mathrm{TM}}$ Bacterial Viability Kit (Molecular Probes) was used, according to the manufacturer's instructions. The Live/Dead kit consists of two reagents containing a mixture of SYTO9 (green) and propidium iodide (red). Germinated fungi were stained for $10 \mathrm{~min}$ and examined using a fluorescence microscope (Olympus, Japan) equipped with a FITC filter (excitation 460-490nm, barrier 520). Cells with intact membranes were labeled with green fluorescence, whereas cells with damaged membranes were stained with red fluorescence.

For the FACS analysis to show the ratio of cell death, the spores of C. gloeosporioides were harvested after treatment with DTD for $24 \mathrm{~h}$, and washed twice with cold PBS buffer. After fixing in $70 \%$ ethanol for $30 \mathrm{~min}$ at $4{ }^{\circ} \mathrm{C}$, cells were washed again with cold PBS buffer, and resuspended in PBS buffer containing PI and Annexin V. At least 10,000 events were analyzed using FACScan (BD FacsCalibur) and CellQuest software (Macintosh, FACStation; Becton Dickinson). Cells were considered necrotic if they were positive for PI as shown in the upper left zone of flow cytometry plots.

\section{In vivo antifungal activity assays of DTD.}

To investigate the disease suppression by DTD treatment, antifungal bioassays were performed with pepper. For simultaneous treatment of DTD, $10 \mu \mathrm{L}$ of spore suspension $\left(5 \times 10^{5}\right.$ $/ \mathrm{ml})$ of $C$. gloeosporioides was mixed with different concentrations of DTD $(0 \sim 1.0 \mathrm{mg} / \mathrm{ml})$, and the mixture was applied to unripe green pepper fruits. As controls, distilled water (DW) and $1 \%$ DMSO solution as vehicle (V) were used in these assays. For pretreatment, DTD solutions with different concentrations ( 0 to $0.5 \mathrm{mg} / \mathrm{ml}$ ) were first applied on unripe pepper fruits and were allowed to air dry for $1 \mathrm{~h}$. Then, $10 \mu \mathrm{l}$ of spore suspension $\left(5 \times 10^{5} / \mathrm{ml}\right)$ was inoculated on the DTD-pretreated spots of fruits. The development of anthracnose symptoms was then monitored at 8 or 9 days after infection by measuring legion formation or spore numbers at the infection sites. In addition, the antifungal bioassay was performed with $C$. coccodes, as described previously (Cho et al. 2006). For this, DTD solutions with different concentrations ( 0 to $1.0 \mathrm{mg} / \mathrm{ml}$ ) were sprayed onto pepper plants. At $24 \mathrm{~h}$ after the spray, the DTD-treated plants were inoculated also, by spraying with the spore suspension of C. coccodes. Disease severity was observed 4 days after infection.

To evaluate in vivo antifungal activity of DTD against other phytopathogens, we investigated the effects of DTD against various diseases such as RCB, RSB, TGM, TLB, and WLR, as well as RPA. The detailed procedures were described in previous reports (Cho et al. 2006; Kim et al. 2001a). For the assays, rice (Oryza sativa L. cv. Nakdong), tomato (Lycopersicon esculentum Mill. cv. Seokwang), wheat (Triticum aestivum L. cv. Chokwang), and pepper (C. annuum L. cv. Nockkwang) plants were grown in vinyl pots $(4.5 \mathrm{~cm}$ in diameter) in greenhouse conditions and were used for the analysis. After spraying with DTD $(0.25,0.50$, and $1.00 \mathrm{mg} / \mathrm{ml})$, disease severity was observed and disease control values $(\%)$ were then calculated, using the following equation: [(disease severity of untreated plants - disease severity of treated plants)/disease severity of untreated plants] $\times 100$.

\section{Expression analysis of $\boldsymbol{P R}$ genes and proteins.}

For gene expression analysis, total RNA was extracted from pepper fruits, using Trizol reagent (Gibco BRL) according to the manufacturer's instructions. Total RNA $(10 \mu \mathrm{g})$ was separated on $1.2 \%$ denaturing agarose gels and was blotted onto a Hybond $\mathrm{N}^{+}$membrane (GE Healthcare). The blots were then hybridized with $\left[\alpha^{32} \mathrm{P}\right] \mathrm{dCTP}-$ labeled respective probes, including defenserelated genes such as $P R 3$ (chitinase class II), PR5 (thaumatinlike protein), and PRIO. The primers used for the probes were described previously (Park et al. 2014; Seo et al. 2014).

For protein expression analysis, $200 \mu \mathrm{g}$ of total protein from each sample was used for electrophoresis in the second dimension as described (Soh et al. 2012). Two-dimensional electrophoresis was performed, using linear immobilized $\mathrm{pH}$ gradient strips of $17 \mathrm{~cm}$ in length, which were stained with silver nitrate after sodium dodecyl sulfate-polyacrylamide gel electrophoresis. The protein expression profiles were compared among proteins from the unripe pepper fruits after treatment with $1 \%$ DMSO, fungal spores, DTD, or a combination of fungal spores and DTD.

\section{Statistical analysis.}

All experimental data were subjected to analysis of variance using IBM SPSS statistics 20 software. Significant differences of mean values were compared by the least significant difference and Duncan's multiple range test at $P<0.05$ or $<0.01$. All the data were represented as the mean \pm standard deviation of at least three independent experiments.

\section{ACKNOWLEDGMENTS}

We thank the Kumho Life Science Laboratory in Chonnam National University for providing plant growth facilities. This work was supported by the Basic Science Research Program through the National Research Foundation of Korea (NRF) funded by the Ministry of Education, Science and Technology (grant no. NRF-2014R1A1A2007413 to Y.S. Kim) and Next-Generation BioGreen 21 Program, Rural Development Administration, Republic of Korea (grant no. PJ01332701 to J.-I. Kim). In addition, this study was financially supported by Chonnam National University, 2016-2017.

\section{LITERATURE CITED}

Aranda, J., Cerqueira, N. M., Fernandes, P. A., Roca, M., Tuñon, I., and Ramos, M. J. 2014. The catalytic mechanism of carboxylesterases: A computational study. Biochemistry 53:5820-5829.

Bayry, J., Aimanianda, V., Guijarro, J. I., Sunde, M., and Latgé, J. P. 2012. Hydrophobins-Unique fungal proteins. PLoS Pathog. 8:e1002700.

Bhattacharjee, S., Halane, M. K., Kim, S. H., and Gassmann, W. 2011. Pathogen effectors target Arabidopsis EDS1 and alter its interactions with immune regulators. Science 334:1405-1408.

Bowman, S. M., and Free, S .J. 2006. The structure and synthesis of the fungal cell wall. Bioessays 28:799-808.

Cannon, P. F., Damm, U., Johnston, P. R., and Weir, B. S. 2012 Colletotrichum-Current status and future directions. Stud. Mycol. 73: 181-213.

Cho, J. Y., Choi, G. J., Lee, S.-W., Jang, K.-S., Lim, H. K., Lim, C. H., Lee, S. O., Cho, K. Y., and Kim, J.-C. 2006. Antifungal activity against Collectotrichum spp. of curcuminoids isolated from Curcuma longa $\mathrm{L}$. rhizomes. J. Microbiol. Biotechnol. 16:280-285.

Cho, K. C., Han, Y. J., Kim, S. J., Lee, S. S., Hwang, O. J., Song, P. S., Kim, Y. S., and Kim, J. I. 2011. Resistance to Rhizoctonia solani AG-2-2 (IIIB) in creeping bentgrass plants transformed with pepper esterase gene PepEST. Plant Pathol. 60:631-639.

Crouch, J. A., and Beirn, L. A. 2009. Anthracnose of cereals and grasses. Fungal Divers. 39:19-44.

Cummins, I., Landrum, M., Steel, P. G., and Edwards, R. 2007. Structure activity studies with xenobiotic substrates using carboxylesterases isolated from Arabidopsis thaliana. Phytochemistry 68:811-818. 
Fesel, P. H., and Zuccaro, A. 2016. $\beta$-glucan: Crucial component of the fungal cell wall and elusive MAMP in plants. Fungal Genet. Biol. 90:53-60.

Feys, B. J., Moisan, L. J., Newman, M. A., and Parker, J. E. 2001. Direct interaction between the Arabidopsis disease resistance signaling proteins, EDS1 and PAD4. EMBO J. 20:5400-5411.

Gan, P., Ikeda, K., Irieda, H., Narusaka, M., O’Connell, R. J., Narusaka, Y., Takano, Y., Kubo, Y., and Shirasu, K. 2013. Comparative genomic and transcriptomic analyses reveal the hemibiotrophic stage shift of Colletotrichum fungi. New Phytol. 197:1236-1249.

Gow, N.A.R., Latge, J.P., and Munro, C.A. 2017. The fungal cell wall: Structure, biosynthesis, and function. Microbiol. Spectr. 5 Published online. doi.org/10.1128/microbiolspec.FUNK-0035-2016.

Harp, T. L., Pernezny, K., Ivey, M. L. L., Miller, S. A., Kuhn, P. J., and Datnoff, L. 2008. The etiology of recent pepper anthracnose outbreaks in Florida. Crop Prot. 27:1380-1384.

Kim, J.-C., Choi, G. J., Park, J.-H., Kim, H. T., and Cho, K. Y. 2001 a. Activity against plant pathogenic fungi of phomalactone isolated from Nigrospora sphaerica. Pest Manag. Sci. 57:554-559.

Kim, Y. S., Lee, H. H., Ko, M. K., Song, C. E., Bae, C. Y., Lee, Y. H., and Oh, B. J. 2001b. Inhibition of fungal appressorium formation by pepper (Capsicum annuum) esterase. Mol. Plant-Microbe Interact 14:80-85.

Ko, M., Cho, J. H., Seo, H. H., Lee, H. H., Kang, H. Y., Nguyen, T. S., Soh, H. C., Kim, Y. S., and Kim, J. I. 2016. Constitutive expression of a fungus-inducible carboxylesterase improves disease resistance in transgenic pepper plants. Planta 244:379-392.

Ko, M. K., Jeon, W. B., Kim, K. S., Lee, H. H., Seo, H. H., Kim, Y. S., and Oh, B. J. 2005. A Colletotrichum gloeosporioides-induced esterase gene of nonclimacteric pepper (Capsicum annuum) fruit during ripening plays a role in resistance against fungal infection. Plant Mol. Biol. 58:529-541.

Liu, F., Tang, G., Zheng, X., Li, Y., Sun, X., Qi, X., Zhou, Y., Xu, J., Chen, H., Chang, X., Zhang, S., and Gong, G. 2016. Molecular and phenotypic characterization of Colletotrichum species associated with anthracnose disease in peppers from Sichuan Province, China. Sci. Rep. 6:32761.

Ménard, R., Alban, S., de Ruffray, P., Jamois, F., Franz, G., Fritig, B., Yvin, J. C., and Kauffmann, S. 2004. $\beta-1,3$ Glucan sulfate, but not $\beta-1,3$ glucan, induces the salicylic acid signaling pathway in tobacco and Arabidopsis. Plant Cell 16:3020-3032.

Morris, M. J., Liu, D., Weaver, L. M., Board, P. G., and Casarotto, M. G. 2011. A structural basis for cellular uptake of GST-fold proteins. PLoS One 6:e17864.

Münch, S., Lingner, U., Floss, D. S., Ludwig, N., Sauer, N., and Deising, H. B. 2008. The hemibiotrophic lifestyle of Colletotrichum species. J. Plant Physiol. 165:41-51.

O'Connell, R. J., Thon, M. R., Hacquard, S., Amyotte, S. G., Kleemann, J., Torres, M. F., Damm, U., Buiate, E. A., Epstein, L., Alkan, N., Altmüller, J., Alvarado-Balderrama, L., Bauser, C. A., Becker, C., Birren, B. W., Chen, Z., Choi, J., Crouch, J. A., Duvick, J. P., Farman, M. A., Gan, P., Heiman, D., Henrissat, B., Howard, R. J., Kabbage, M., Koch, C.,
Kracher, B., Kubo, Y., Law, A. D., Lebrun, M. H., Lee, Y. H., Miyara, I., Moore, N., Neumann, U., Nordström, K., Panaccione, D. G., Panstruga, R., Place, M., Proctor, R. H., Prusky, D., Rech, G., Reinhardt, R., Rollins, J. A., Rounsley, S., Schardl, C. L., Schwartz, D. C., Shenoy, N., Shirasu, K., Sikhakolli, U. R., Stüber, K., Sukno, S. A., Sweigard, J. A., Takano, Y., Takahara, H., Trail, F., van der Does, H. C., Voll, L. M., Will, I., Young, S. Zeng, Q., Zhang, J., Zhou, S., Dickman, M. B., Schulze-Lefert, P., Ver Loren van Themaat, E., Ma, L. J., and Vaillancourt, L. J. 2012. Lifestyle transitions in plant pathogenic Colletotrichum fungi deciphered by genome and transcriptome analyses. Nat. Genet. 44:1060-1065.

O’Connell, R. J, Pain, N. A., Hutchison, K. A., Jones, G. L., and Green, J. R. 1996. Ultrastructure and composition of the cell surfaces of infection structures formed by the fungal plant pathogen Colletotrichum lindemuthianum. J. Microsc. 181:204-212.

Oliveira-Garcia, E., and Deising, H. B. 2013. Infection structure-specific expression of $\beta$-1,3-glucan synthase is essential for pathogenicity of Colletotrichum graminicola and evasion of $\beta$-glucan-triggered immunity in maize. Plant Cell 25:2356-2378.

Park, S., Park, A. R., Im, S., Han, Y. J., Lee, S., Back, K., Kim, J. I., and Kim, Y. S. 2014. Developmentally regulated sesquiterpene production confers resistance to Colletotrichum gloeosporioides in ripe pepper fruits. PLoS One 9:e109453.

Pontier, D., Tronchet, M., Rogowsky, P., Lam, E., and Roby, D. 1998. Activation of $h s r 203$, a plant gene expressed during incompatible plantpathogen interactions, is correlated with programmed cell death. Mol. Plant-Microbe Interact 11:544-554.

Rawlings, S. L., O'Connell, R. J., and Green, J. R. 2007. The spore coat of the bean anthracnose fungus Colletotrichum lindemuthianum is required for adhesion, appressorium development and pathogenicity. Physiol. Mol. Plant Pathol. 70:110-119.

Saxena, A., Raghuwanshi, R., Gupta, V. K., and Singh, H. B. 2016. Chilli anthracnose: The epidemiology and management. Front. Microbiol. 7:1527.

Segonzac, C., and Zipfel, C. 2011. Activation of plant pattern-recognition receptors by bacteria. Curr. Opin. Microbiol. 14:54-61.

Seo, H. H., Park, S., Park, S., Oh, B. J., Back, K., Han, O., Kim, J. I., and Kim, Y. S. 2014. Overexpression of a defensin enhances resistance to a fruit-specific anthracnose fungus in pepper. PLoS One 9:e97936.

Soh, H. C., Park, A. R., Park, S., Back, K., Yoon, J. B., Park, H. G., and Kim, Y. S. 2012. Comparative analysis of pathogenesis-related protein 10 (PR10) genes between fungal resistant and susceptible peppers. Eur. J. Plant Pathol. 132:37-48.

Than, P. P., Prihastuti, H., Phoulivong, S., Taylor, P. W., and Hyde, K. D. 2008. Chilli anthracnose disease caused by Colletotrichum species. J. Zhejiang Univ. Sci. B 9:764-778.

van Loon, L. C., Rep, M., and Pieterse, C. M. 2006. Significance of inducible defense-related proteins in infected plants. Annu. Rev. Phytopathol. 44:135-162. 